\title{
O Imaginário sobre Getúlio Vargas
}

\author{
Maria de Lourdes Mônaco Janotti”
}

Resumo: A intenção deste artigo é analisar traços marcantes do imaginário social presentes nos depoimentos coletados pelo projeto Estado Novo na Memória e na Historiografia. No conjunto documental registrado, observa-se que o imaginário sobre Getúlio Vargas se cristaliza durante - Estado Novo, nâo se atendo às contingências temporais que ocorreram durante o extenso período em que esteve no poder. Vargas é representado como sendo sempre o mesmo homem imperturbável e seguro, sem hesitações ou medos, sabendo como agir e premeditando com exatidáo o próximo passo a ser dado. As narrativas obscurecem todos os impasses próprios da condiçăo política e as mudanças que ocorrem na personalidade durante uma trajetória de vida; o homem de 1930 prefigurava o de 1954. As representações comparativas dos depoentes sobre o Estado Novo e a ditadura militar de 64 , desfavoráveis a esta última, empalideceram o "lado negro" do regime anterior, ao mesmo tempo em que afirmavam ser o presente uma experiência única e desalentadora, sem parâmetros no passado.

Palavras-chave: imaginário social - Getúlio Vargas - Estado Novo - ditadura militar de 1964

O projeto Estado Novo na Memória e na Historiografia, desenvolvido conjuntamente com alunos do curso de graduação em História, teve como principal objetivo perceber as correlações que pessoas - de diferentes atividades profissionais e posturas ideológicas - estabeleceram entre o Estado Novo e a ditadura militar instaurada em $1964 .{ }^{1}$ Os depoimentos coletados revelaram traços marcantes do imaginário social sobre a história política contemporânea, construídos em torno dos julgamentos emitidos sobre Getúlio Vargas.

Foram colhidos quarenta depoimentos temáticos, acompanhados das respectivas autorizações, transcrições e anotações sobre o trabalho de campo e, além desses, 13 que não preenchem todas as exigências mencionadas, razão pela qual não foram analisados nesse trabalho. O corte do grupo entrevistado foi bastante amplo, orientado pela sondagem realizada e pela necessidade de facilitar o desempenho dos alunos - entrevistadores que atuaram no projeto. O prin-

\footnotetext{
"Professora do Departamento de História da FFLCH-USP.
} 
cipal vínculo exigido dos depoentes era ter estado no mercado de trabalho na época rememorada mas, frente ao significado do movimento estudantil contra a ditadura, foi introduzida a categoria estudantes junto às demais arroladas.

O corpo de entrevistados foi selecionado segundo as categorias profissionais divididas da seguinte forma: trabalhadores autônomos; trabalhadores de empresas privadas subdivididas em ramo industrial, financeiro, comercial, rural e comunicações; trabalhadores do setor público vinculados às Secretarias do Estado de São Paulo da Educação, da Segurança Pública, de Viação e Obras Públicas e militares.

As categorias profissionais representadas foram as seguintes: carpinteiro, eletricista, alfaiate, operários industriais, vendedor, bancários, contínuo, escriturário, escrivão de polícia, guarda civil, ferroviários, motorista, motorneiro, gráficos, químico, professores, jornalistas, trabalhador rural. Os entrevistados eram em sua maioria do sexo masculino, registrando-se apenas entrevistas de duas professoras e uma operária.

Embora tenha-se adotado como norma respeitar a liberdade de rememorar do entrevistado, elaborou-se uma lista de assuntos que poderiam ou não ser introduzidos no diálogo entre o depoente e o pesquisador, conforme se apresentasse a oportunidade. Contudo, devido ao caráter de aprendizagem inerente ao projeto, alguns alunos seguiram a lista rigorosamente, imprimindo um caráter diretivo à entrevista. Pensamos que isto não invalida a qualidade do discurso registrado, desde que seja considerado pelo analista. Convém observar que todos os passos do trabalho foram percorridos pelos alunos - incluindo a análise -, discutidos em grupo e devidamente supervisionados. Em várias ocasiōes foi necessário o retorno à pesquisa de campo.

Por que pesquisar sobre o Estado Novo em 1983? Nesse momento em que, sob o governo do general João Batista de Oliveira Figueiredo (1979-85), o país caminhava para uma supervisionada saída da ditadura militar, começaram a ser publicadas diversas autobiografias de militantes e políticos atuantes na luta contra o autoritarismo desde 1930. A historiografia, por sua vez, a partir dos fins dos anos 70, havia se debruçado sobre a "era Vargas" e o populismo na tentativa de compreender a derrocada das instituições democráticas. Embasados nessa bibliografia e nas primeiras leituras sobre histórias de vida e historia oral que tivemos acesso, elaboramos o projeto.

Tinha-se a suspeita e a esperança, ambas confirmadas, de que as pessoas não sentiriam mais tanto medo em falar de política. Todavia, para atingir os objetivos traçados, adotou-se a estratégia de centrar as entrevistas especialmente sobre o mundo do trabalho e a repressão durante o Estado Novo, período historicamente encerrado, e deixar que o depoente estabelecesse espontaneamente correlações com a atualidade, mesmo porque o ferrete da contemporaneidade é inerente a qualquer 
pronunciamento oral ou escrito. É de se notar que dois depoentes foram interrompidos por familiares temerosos quando faziam restrições aos generais presidentes.

A abrangência cronológica explícita na maioria das entrevistas estendeu-se dos antecedentes da revolução de 30 até o suicídio de Getúlio Vargas em 1954, no entanto, implicitamente foram considerados os anos que permeiam 54 a 83 . Entre os temas privilegiados pelos entrevistados estão: as apreciações sobre a figura de Vargas, as condições de trabalho e as relações sindicais, o julgamento do Estado Novo e o panorama internacional - fascismo, nazismo, influência americana, comunismo, Segunda Guerra Mundial.

O esforço em reconstruir a história da época evidencia-se fortemente ao longo das gravações e quando o entrevistado pede ao entrevistador que confirme as datas dos acontecimentos referidos. Também percebe-se várias retomadas da narrativa para a autocorreção. Por esta razão, e não aleatoriamente, faremos referências gerais ao amplo contexto histórico que entrelaça o discurso dos depoentes.

\section{RECONSTRUINDO A HISTÓRIA}

Ainda hoje sobrevive na memória histórica e popular, como igualmente nos diferentes discursos de caráter político, um forte apelo à imagem de Vargas. Por mais que se queira relativizar a ação individual na história, é impossível deixar de reconhecer a importância de Getúlio Vargas que, apesar de formado no seio da sólida oligarquia sulina, conseguiu ultrapassar os limites da política regional e se manter por tantos anos como principal protagonista do drama político-institucional do país, em época de turbulentas mudanças e não menos fortes reações a elas.

Nas rememorações são mencionados os diferentes papéis que assumiu como: chefe do Governo Provisório (1930-34); presidente eleito por sufrágio indireto (1934-37); ditador de 1937 a 1945; senador (1945-51); presidente eleito por sufrágio universal para cumprir o mandato de 1951 a 1956. Os acontecimentos que envolveram sua renúncia na madrugada de 24 de agosto de 1954, seguida por seu suicídio, adquirem relevância e são norteadores dos sentimentos e das opiniões.

Os anos 20 e 30 foram de profundo confronto entre uma sociedade tradicional dominada por senhores de terra, rigidamente hierarquizada, e as reivindicações de setores de classes emergentes da nova sociedade industrial. O Brasil, nessas décadas, presenciou a explosão de forças sociais e políticas oriundas de uma realidade que se alterara substancialmente com a inclusão dos trabalhadores no jogo do poder, bem como da pequena burguesia industrial e das classes médias. 
A revolução de 1930 foi vista com simpatia, pois terminou com a política opressora das oligarquias. Manifestaçöes populares de júbilo acolheram o Governo Provisório nas principais cidades do país, persistindo nas lembranças impressões marcantes sobre o clima de euforia que acompanhou a ascensão de Getúlio ao poder. O respeitado cientista-social Ruy Galvão de Andrada Coelho, em 1983 diretor da Faculdade de Filosofia, Letras e Ciências Humanas da Universidade de São Paulo, relatou suas rememorações do dia da chegada vitoriosa de Vargas a São Paulo:

"Uma das primeiras recordaçōes de minha vida foi no balcão da Rua Líbero Badaró, no escritório do meu pai, em 1930. Meu pai levou a família toda ... para ver a entrada de Getúlio em São Paulo. Ele chegou, ele vinha do Sul. ... E naquele momento havia um entusiasmo imenso na renovação do Brasil ... Eu me lembro ainda da multidão crescendo, crescendo. Ele passou na Rua Líbero Badaró por volta de uma hora. E nós todos, ali, numa vigília de família, com todo mundo que era liberal em São Paulo, que era contrário à República Velha com suas instituiçōes rançosas, com sua ausência total de democracia, eleições com voto a descoberto, totalmente controladas pelas autoridades. ... Era uma renovação política para uma situação de crise grave (1929) e todo mundo estava ao lado do Getúlio. Eu me lembro ainda de ver o automóvel e aquela figurinha miúda de nariz característico. Eu me admirei dele ser tão baixinho. E a multidão completamente alucinada, aos vivas, - Viva os gaúchos! E aparecia, então, aquela tropa dos provisórios: o chapéu gaúcho, o lenço vermelho no pescoço, não eram fardados como o exército. Aquela multidão gigantesca e os gritos de entusiasmo espantoso me deu, posteriormente, idéia do que houve na Itália, na Praça Veneza, aqueles espetáculos imensos; mas era espontâneo. Era o povo inteirinho que estava nas ruas. Getúlio era a esperança da renovação. Esta foi a primeira imagem que eu tive dele. Depois, com o correr do tempo, houve críticas a Getúlio. É evidente que era um homem oportunista, frio, capaz de qualquer coisa para continuar no poder." (Cientista-social, 62 anos. Entrevista concedida a Cecília Vita. São Paulo, out. 1983)

Entretanto, longe estava a pacificação das forças políticas e sociais. Os problemas não se resolveram com medidas legislativas ou discursos bem elaborados; os conflitos não tardaram a surgir. Vargas enfrentou momentos sucessivos de extrema gravidade. Em 1932 venceu a Revolução Constitucionalista, embora tivesse cedido às pressões da oligarquia paulista ao convocar eleições para a Assembléia Constituinte, promulgando, em 1934, uma nova Constituição.

Em 1935 deu-se o levante comunista no Rio de Janeiro, Rio Grande do Norte e Pernambuco. Contra-atacado, foi totalmente vencido. A repressão ao levante foi implacável e seus resultados avassaladores: prisões arbitrárias, torturas, 
mortes e desaparecimentos. O terror implantou-se, toda resistência foi sistematicamente sendo aniquilada.

Mediante tais acontecimentos, começou a escalada para a implantação de uma ditadura varguista no país. Sucessivas decretações de estado de sítio, com o assentimento do Congresso Nacional, cercearam até as liberdades individuais reconhecidas pela Constituição. Durante esta grande crise, na qual Getúlio obteve apoio dos governadores dos Estados, toda a oposição parlamentar foi vencida tendo mesmo sido presos senadores e deputados.

O país foi invadido pela ideologia do anticomunismo, unindo-se em torno dela o governo, as oligarquias, o exército, tenentistas, parte da pequena burguesia e da classe média, bem como as igrejas tradicionais, principalmente a Igreja Católica. Foram instituídos a Comissão de Repressão ao Comunismo e o Tribunal de Segurança Nacional, principais mecanismos de controle ideológico e social, com plena aquiescência da burguesia nacional. Cresceu sobremaneira o número de associações reacionárias organizadas em legiões, comitês, ligas anticomunistas.

A Ação Integralista Brasileira, organização de extrema direita inspirada na doutrina fascista, fundada em 1932, sob a chefia de Plínio Salgado, promovia passeatas ostensivas contra os comunistas, ganhando prestígio e influência crescentes junto à classe média e entre os católicos. Getúlio Vargas manteve sempre uma relação ambígua com Plínio Salgado e com o integralismo. Nesse momento, serviuse da AIB para criar um clima de pânico, beirando a paranóia, que poderia popularmente ser traduzido por: cuidado, o pior ainda vai suceder e os comunistas vão nos matar a todos! Era a escalada para a ditadura: o Estado Novo.

O golpe contra as instituições democráticas organizava-se dentro do próprio governo constitucional e das Forças Armadas. Lançada antecipadamente, em abril de 1937, a campanha presidencial forneceu elementos para que o plano prosseguisse. Nessa ocasião, divulgou-se o "Plano Cohen", documento nitidamente forjado pelos conspiradores governistas, cuja autoria foi atribuída ao Partido Comunista, no qual ficava claro que uma nova revolução seria imediatamente deflagrada. Esse documento foi considerado pelos próprios contemporâneos como uma falsificação provocativa destinada a reforçar as intenções de um golpe de Estado. E foi isso o que sucedeu.

Em 10 de novembro de 1937 foi outorgada uma nova Constituição instituindo o Estado Novo, acompanhada por discurso de Getúlio Vargas e pela proclamação do ministro da guerra, general Eurico Gaspar Dutra.

A nova Constituição era extremamente centralizadora e seguia os princípios da racionalização do Estado e da sociedade civil. Concedia um mandato de 6 anos ao chefe do governo e dissolvia os órgãos do Legislativo. Previa também a realização de um plebiscito, a ser marcado em "hora oportuna". Os partidos foram dis- 
solvidos, bem como todas as demais organizações políticas da sociedade civil. Não seria a primeira vez, nem a última, que se empregaria o argumento de que a democracia estava ameaçada para se instituir uma ditadura. Em 1964 foi o mesmo.

Instituída a ditadura, Plínio Salgado sentiu-se traído por Vargas ao ver frustradas suas esperanças de exercer um papel de destaque no governo, mas continuou a manter com o ditador e com o sinistro chefe de polícia, Filinto Muller, contatos secretos. Logicamente, além de Getúlio precisar atender aos seus aliados da direita conservadora do exército, ainda era cedo para descartar uma organização paramilitar, que no futuro poderia ser-lhe útil.

Os integralistas cindiram-se perante o Estado Novo. Havia os que apoiaram a nova situação porque esta significava o fim do liberalismo, a perseguição tenaz ao movimento das esquerdas e a adoção de uma de suas principais bandeiras, o corporativismo, como princípio organizador das relações sociais. Ao contrário destes, os inconformados não aceitaram passivamente sua exclusão da partilha do poder.

A rebeldia integralista manifestou-se, inicialmente, através de pequenos episódios em diferentes estados, tomando vulto em 11 de maio de 38 . A conspiração aglutinou grupos heterogêneos: integralistas, liberais oposicionistas e membros do exército não alinhados com o Estado Novo. O ataque de surpresa ao Palácio não encontrou nenhuma resistência significativa. Provavelmente houve omissão das forças que deveriam proteger o presidente, evidenciando a existência de implicados entre os responsáveis pela segurança. Após algumas horas sem socorro, sabedores do acontecido e por iniciativa própria, Cordeiro de Farias e João Alberto, fiéis amigos do presidente, reuniram tropas e venceram os revoltosos.

A ação da polícia política e da justiça desabou sobre todos os oposicionistas e, particularmente, sobre os integralistas. Traindo seus correligionários, Plínio Salgado negou qualquer responsabilidade nos acontecimentos.

Esses eventos são referenciais no discurso narrativo coletado, apesar de nem sempre obedecerem ao rigor cronológico. Isso demonstra a familiaridade dos depoentes, independentemente de seu grau de escolaridade, com o passado público, sobejamente comprovado pela recorrência a nomes de ministros, deputados, militares, sindicalistas da época. Informavam-se através de jornais, revistas e programas de rádio. Falava-se de política nos sindicatos, nas fábricas, nos grêmios estudantis e nas rodas de convivência.

No discurso memorialístico é impossível separar o imaginário sobre a personalidade de Vargas do contexto conjuntural.

Até hoje Vargas tem sido uma figura recorrente no imaginário político-social. Não é raro durante as campanhas eleitorais partidos de diferentes matizes ideológicos recorrerem à sua figura e ao seu nome para pleitear a simpatia popu- 
lar pois, sem dúvida, foi no seio da antiga classe trabalhadora que se solidificou sua memória de demiurgo das conquistas sociais. Sua fotografia era freqüentemente exposta nas casas de trabalhadores junto às de parentes queridos. Por ocasião das entrevistas, operários fizeram questão de exibir fotografias e recortes de jornais com a figura de Vargas.

Os contemporâneos costumam referir-se a Getúlio como um homem enigmático, sempre aparentando uma bonomia que ocultava uma personalidade fortemente calculista. As impressões sobre Vargas são contraditórias e complementares.

Muitas das imagens sobre Getúlio Vargas foram construídas ao longo dos anos que esteve no poder e solidificaram-se, sem dúvida, durante o Estado Novo, quando os órgãos de propaganda dominaram e invadiram os meios de comunicação. Enquanto os depoimentos de trabalhadores sem credo ideológico declarado referem-se a Getúlio como um homem cordial, de hábitos simples e sensível às necessidades do povo, os militantes políticos preferem qualificá-lo como inteligente e hábil manobrador político.

Exemplo do primeiro caso é a seguinte declaração de um trabalhador gráfico:

“... Getúlio Vargas era tudo para mim. Eu não admitia que ninguém falasse mal do homem. Eu ficava entusiasmado quando ouvia esse homem falar no rádio ... eu não era político, nem entendia disso, mas quando sabia que o homem ia falar eu dizia para minha mãe: 'hoje tem fala do Getúlio, eu quero escutar'. Ficava sempre entusiasmado, mesmo sem entender nada daquilo lá, mas eu sabia o benefício que a gente teve, tinha minha carteirinha, tinha tudo! Eu pensava: agora sou operário, agora sim estou garantido. Eu só tenho que falar bem desse homem, não posso falar mal nenhum." (Gráfico, 83 anos, preferiu permanecer anônimo. Entrevista concedida a Rita de Cássia Rossi. São Paulo, 22/10/1983)

A política trabalhista do governo era dúbia; se por um lado desmobilizava o movimento operário, reprimindo o sindicalismo livre, por outro promovia a institucionalização do novo sindicalismo, apoiando lideranças submissas. Incentivava também reivindicaçōes proletárias baseadas nos direitos conquistados pelos trabalhadores na Constituição e, muitas vezes, favorecia movimentos grevistas. Perigoso jogo político, habilmente manobrado por Vargas, que amedrontava a burguesia e neutralizava as correntes ideológicas do movimento operário. Em grande parte, a luta inicial dos anarquistas desapareceu da memória; apagada pela política trabalhista e pela repressão governamental que desagregaram os grupos militantes. 
Moisés Florêncio da Silva, mecânico do setor eletricitário, vê favoravelmente a interferência do Estado na condução da política sindical:

"Em 35 eu fui sindicalizado pelo Sindicato e União dos Trabalhadores da Light. E cm 37 passei a ser sindicalizado pelo Sindicato das Indústrias Mecânicas e Elétricas de São Paulo. Eu apenas tomei parte no Sindicato dos Metalúrgicos de São Paulo.

(O sindicato) era representante dos operários, não deixando de ter ligações com o Estado; vivia sob os decretos e os esclarecimentos do ex-ministro do trabalho Alexandre Marcondes Filho.

... Nessa época, nós, operários, nunca tivemos queixa dos sindicatos operários, porque nunca fomos decepcionados pelos sindicatos. $\mathrm{O}$ sindicato programava e orientava o operariado para exigir, foi daí, dessa época para cá, que começou a existir grevc, porque antes eu não conhecia isso aí, vim conhecer depois do sindicato. E, então, cles nunca levaram a gente para o abismo, sempre levaram para o bem, sempre aconselharam o operário como tinha que se comportar perante a indústria, com os patrões $c$ também com os seus direitos, de acordo com os esclarecimentos que eles davam à classe operária.

... Nunca tomei conhecimento que tivesse havido uma intervenção em qualquer sindicato do Brasil nessa época. Quando o sindicato programava uma passeata de protesto com o operariado, não existia coação, não existia perseguição ... Sempre foi um bom sindicato c parece-me que elc tinha uma autonomia, um direito dado pelo governo de Gctúlio Vargas ... Nunca houve intervenção, nunca ouvi falar que foi preso nenhum operário por movimento grevista ou por qualquer desses motivos políticos. Não tenho o que dizer dele e nem dos seus dirigentes.

... Era mesmo através da Hora do Brasil, que todo mundo assistia na época, que havia uma parte do Ministério do Trabalho que dava todos esses esclarecimentos, orientando o operariado como tinha que se organizar e aonde tinha que se dirigir. E o único ponto que eles davam era o sindicato, que todos deviam se dirigir aos sindicatos e se sindicalizarem para poder ter um órgão que trabalhasse em defesa de seus direitos." (Mecânico, 73 anos. Entrevista concedida a Maria Raquel Apolinário. São Paulo, 16/11/1983)

Carlos Escobar, do movimento sindicalista atrelado ao governo, também ofereceu um depoimento de irrestrita admiração a Vargas, recorrendo, contudo, a argumentos bem diversos:

"Naquele tempo eu era bancário profissional, mas agia politicamente, tanto que tinha sido fundador e era vice-presidente do sindicato dos bancários de Santos, onde comandei uma greve e fui mesmo convidado a ser deputado classista, o que não fiz porque não tinha idade. 
... O sindicato é uma das grandes obras de Getúlio Vargas. Ele é que o criou em 1932 e aceitava o sindicato como algodão entre dois cristais - o capitalista e o operário. Nós fomos estimulados a formar o sindicato. ... Getúlio fazia uma eminente política social. $O$ apelido que lhe deram de 'pai dos pobres' não é fora de propósito; ele tinha grande preocupação com a pobreza, com a agricultura, com o estado material do povo brasileiro. O sindicato teve uma grande projeção no Brasil daqucla época, visando primeiro conscientizar as massas trabalhadoras para o papel que elas deveriam desempenhar numa República Sindicalista. ... Não era mais um questão gratuita de decretos, era uma luta de classes, impondo uma política de classes.

As minhas palavras sempre são de simpatia e de entusiasmo por Getúlio Vargas. Eu o considero um dos maiores políticos do Brasil ... apesar das perseguiçōes políticas de Filinto Muller ..., das reações que toda a ditadura causa, ... da prisão por 10 anos do maior líder comunista do Brasil, Luís Carlos Prestes e da entrega da mulher dele, uma alemã (Olga Benário), para ... Hitler, que depois veio a sacrificá-la na Alemanha. Mas Getúlio Vargas, acima de todos esses desmandos, foi tão grande que (no fim do Estado Novo) foi até apoiado pelo próprio Luís Carlos Prestes." (Bancário, 72 anos. Entrevista concedida a Claudia Antinori Passeggio. São Paulo, 12/10/1983)

Entretanto, para Severino Famá, comerciário na década de 40, socialista e atuante nos "sindicatos livres", a repressão violenta do Estado Novo sufocou e desmobilizou o movimento operário:

"Eu sempre achei Getúlio Vargas um grande demagogo. Sem dúvida nenhuma, um líder carismático que deu aos trabalhadores uma situação de relativa garantia ... com as leis trabalhistas por ele promulgadas. (Contudo) restringiu a liberdade sindical e o direito de greve dos operários; isto não foi e nem é focalizado como deveria ser no meio operário ...

... Getúlio foi inteligente, de extremada sensibilidade, demagogo, sabia manobrar as massas; foi tido como o 'Pai dos Trabalhadores' graças à CLT, que era baseada na Carta del Lavoro fascista adaptada às nossas condiçōes. ... Pelo operariado ele era bem visto, pelos demais ele era considerado ditador. (Não havia) liberdade de expressão, a imprensa era controlada pelo DIP, notícias só cram dadas daquilo que interessava ao regime.

... Os sindicatos (de esquerda) atuavam na clandestinidade, (nos demais) os presidentes dos sindicatos, pessoas impostas pelos órgãos governamentais, eram chamados de pelegos. Somente obedeciam às ordens de Getúlio e do Ministério do Trabalho. Para mim não havia vida sindical e quando ela existia era porque havia necessidade de se reivindicar algum direito trabalhista. As reuniões eram feitas às escondidas, clandestinamente, e sofríamos a perseguição da polícia da época ... As associações políticas eram todas clandestinas. 
... Por ser adepto do Partido Socialista eu sempre fui contra o regime do Getúlio, por achá-lo de repressão, c como a liberdade de expressão do indivíduo é sagrada, sempre fui contra qualquer opressão. Sempre fui adepto da teoria de que uma idéia se combate com outra idéia e nunca com repressões." (Comerciário, 68 anos. Entrevista concedida a Claudia Padilha Furlai. São Paulo, 26/10/1983)

Marcos Andreotti, sindicalișta e socialista, tem sólidas opiniões contrárias ao regime baseadas em sua experiência como presidente do Sindicato dos Metalúrgicos de 1933 a 1937 em Santo André.

"Fui fundador e presidente do sindicato aqui (Sto. André) c antes havia participado da União Opcrária, que mais tarde foi fechada pela polícia.

... (O Estado Novo) foi o pior governo que nós tivemos, porque Getúlio quando deu o Golpe estava marchando diretamente para o fascismo, e se não fosse a grande luta descmpenhada pelo povo brasileiro e a pressão do imperialismo americano ele cairia nos braços do fascismo e estaria com o Eixo. ... Getúlio era um político muito hábil, usava muito a demagogia para induzir o povo, principalmente o trabalhador, chegando a criar, até mesmo, o Queremismo - que arrastava o povo - isto devido a sua demagogia e habilidade política. Usava também da propaganda em jornais, revistas, programas de rádio. Como era tudo controlado eu lia jornais clandestinos e outros.... Getúlio $\mathrm{cm}$ toda sua carreira foi um governo vacilante cntre o povo e o capitalismo.

... No período de 1937 a 1945 houve uma repressão muito grande, porque Getúlio não podendo mais conter as reivindicações $\mathrm{c}$ as manifestações dos trabalhadores, (havia conflitos entre o Integralismo e os trabalhadores $\mathrm{cm}$ geral, inclusive o partido comunista), instituiu o Estado Novo, cerceando todas as liberdades, inclusive intervindo nos sindicatos, usando a Carta fascista que ele havia trazido.

... O governo ameaçava os sindicatos que se destacavam em reivindicações na luta do trabalhador, aqueles que procuravam trabalhar rcalmente em defesa do trabalhador, esse sindicato era mais controlado pelo governo. Nas assembléias vinham policiais e nós tínhamos que dar a ordem do dia da Assembléia para o governo controlar. Nessa época, Getúlio criou por um decreto a polícia operária, que era um trabalhador dentro da fábrica com função policial para verificar o que o trabalhador dizia, como agia, etc. Aparentemente teve uma melhora na organização da classe operária, mas na realidade foi pior, pois havia policiamento no meio do trabalhador.

... Nessa ćpoca cu cstava afastado da presidência do sindicato, pois houve duas intervenções nesse período, eu tive que ficar clandestino, fui preso e condenado a 2 anos (1939-1941). Em fins de 1941 saí e fui preso novamente, e depois da guerra fui anistrado pelo governo de Getúlio. 
... A gente tem que recordar muita coisa, a luta foi muito grande até se chegar ao que é hoje, e hoje está pior ainda ... A situação do trabalhador hoje, comparando com a época de Getúlio, é péssima. Pela situação que o país atravessa com essa crise, e o nosso governo se entregando ao FUNDO MONETÁRIO INTERNACIONAL acarreta maiores dificuldades para o povo, não é? Então o nosso governo está entregue ao FMI, quem dá as ordens aqui não ć o seu Figueiredo, mas sim o FMI, e isso vai levar o país às piores conseqüências. Naquela época existia o imperialismo americano, que predominava no governo, mas era mais brando que o FMI." (Eletricista, 73 anos. Entrevista concedida a Sônia Maria Moldes. Santo André, 22/10/1983)

Esse confronto de julgamentos quanto à política sindical expressa o fortalecimento de uma memória hegemônica sobre as conquistas sociais dos trabalhadores. Um dos depoentes adverte para o esquecimento da repressão sobre as lutas da esquerda e a aceitação passiva de que os benefícios sociais foram concessões, mas reconhece, ao mesmo tempo, que o sindicalismo foi fortalecido pelo Estado Novo. Impasse complexo presente nos julgamentos sobre os governos populistas.

\section{COMPARANDO DUAS DITADURAS}

Para os depoentes sem vinculação política, a figura simpática e familiar de Vargas opunha-se às dos generais de 64, sisudos, sombrios, sem nenhuma identificação afetiva com o povo. As dificuldades da vida cotidiana dos anos 40 foram consideradas muito inferiores às que foram vivenciadas após 64 . A censura é um tema importante das rememorações. Todos se referiram às piadas que eram divulgadas sobre Getúlio, às charges publicadas, principalmente as de Belmonte, às paródias da dupla caipira Alvarenga e Ranchinho, sempre salientando que a censura getulista podia incomodar os artistas, mas não os impedia de reincidir nas críticas, ao contrário da implacabilidade do regime militar sobre os meios de comunicação.

A repressão da época de Vargas foi considerada muito branda, voltada apenas contra os comunistas e integralistas, enquanto que a do golpe de 64 atemorizou toda a sociedade, na medida em que muitos inocentes foram presos, torturados e mortos. Filinto Muller, autoridade máxima da polícia getulista, sobrevive nessas lembranças como único responsável pelos excessos da repressäo dessa época. Muitos chegaram mesmo a asseverar que Getúlio nada sabia das maldades por ele executadas.

Dentro de uma perspectiva comparativa favorável a Vargas, o depoente Milton Mascarenhas, corretor de café no interior de São Paulo nas décadas de 30 e 40, declarou: 
"Getúlio foi um grande político, talvez o maior que nós tivemos no Brasil. ... ( $\mathrm{Na}$ época de sua) ditadura, o exército vivia dentro da caserna tratando de seus afazeres (alusão a 64 quando os militares exerceram diretamente o poder). Getúlio fez o maior governo dentro do Brasil. Sobretudo porque pegou o governo em uma situação péssima, pois o PRP e o PRM só tratavam de política. Pegou a época da crise mundial, que aqui chamam de crise do café e conseguiu apesar disto tudo dar um novo andamento para o país. Sem perseguições, sem nada. Depois que cle caiu diziam que havia rombo (nos cofres públicos). Mas não existia, nada ficou provado. Tinha fazendas, mas cram do pai, da família toda, não tinha este aproveitamento de hoje. O funcionalismo ganhava pouco, generais andavam de bonde, não existia todo este movimento." (Entrevista concedida a João Batista Mascarenhas. Ribeirão Preto, 21/10/1983)

Sentimentos de admiração e segurança em relação ao Estado Novo mesclamse ao medo em enfrentar o presente e o futuro no depoimento da operária aposentada Antonieta Burti Gracioso:

"Era a ditadura. Mas eu achava que a ditadura era muito boa, porque eu achava que Getúlio Vargas governava muito bem, especialmente para a classe operária. Ele pôs Leis para a gente, favoreceu bastante a classe operária. Ele pôs a aposentadoria, cle pôs o salário mínimo, elc pôs todas estas coisas, por isso que a gente gostava dele. E não tinha. esse aumento que tem agora, o preço cra esse preço e continuava sendo ano após ano.

Um pobre que queria ter um dinheirinho para se comprar um terreno. Naquele tempo a gente comprava um terreninho para construir. Você ajuntava primeiro o dinheiro, até que você comprava, e você conseguia, porque depois de 10 anos o preço era o mesmo.

... Então $\mathrm{cm} \mathrm{45,} \mathrm{quando} \mathrm{Getúlio} \mathrm{foi} \mathrm{deposto,} \mathrm{eu} \mathrm{chorei} \mathrm{bastante.} \mathrm{Eu} \mathrm{fiquei...}$ até eu achava que a gente devia se revoltar, porque ele tinha sido um bom governo. Por que é que tinham que trocar? Para mim ele era o máximo...

Era excelente. Vocês não acham, não é? Eu falo agora com meus netos e eles não acham. Mas para mim ele foi um excelente governo. De paz, viu minha filha. Você tinha paz mesmo, viu! Agora a gente não tem paz. Ou é porque a gente agora é velha!

... Eu ando amedrontada com meus filhos agora, com esse tempo de agora. Eu tenho tanto medo, meu Deus. Só fico, fico ajoelhada rezando para Deus guardar. Porque a gente não vê mais que ninguém te guarda mais aqui. Não vê mesmo!. Deus me livre... mas como está essa ćpoca de agora! É verdade ou não é?" (Operária do Cotonifício Rodolfo Crespi, 72 anos. Entrevista concedida a Denise M. Cavalcante Gomes. São Paulo, 14/10/1983) 
Oscar Villa Bella começou a trabalhar aos 11 anos de idade em uma tipografia. Durante o Estado Novo trabalhava como linotipista no jornal Hoje, que era do Partido Comunista, em São Paulo. Seu depoimento é muito rico em relação ao cotidiano da vida jornalística, pois trabalhou em diversos jornais. Lembra-se de desaparecidos e torturados na época de Getúlio, assim como das campanhas populares e passeatas. Faz questão de mencionar que não é comunista e expressar seu inconformismo sobre a situação do país.

"O Estado Novo era uma ditadura com outro nome, como hoje essa Revolução de 64, que para mim não foi revolução, foi tirar o Jango de lá e você ficar no lugar do Jango. ... O homem mais pavoroso que eu considero atualmente é esse Jânio Quadros, pulou de partido $\mathrm{cm}$ partido e abandonou a todos, só não entrou no PC. Renunciou sem motivos.

... Nós tínhamos naquela época um jornal, Hoje, do PC aqui em São Paulo. Esse jornal Hoje contava tudo, dizia tudo que Getúlio era, o quc estava fazendo, as perseguições dos ministros e as cassaçōes. A polícia, por sua vez, agia como hoje faz o esquadrão da morte, mata e depois diz que a pessoa morreu por acidente; quem vai provar o contrário?

... Digo a verdade, muita gente fá confusão comigo, cu não sou comunista, mas já passei prisão como comunista durante o Estado Novo e fiz a primeira greve de fome no Brasil, devido a um crime que a polícia praticou aqui no Paraiso (referc-se à tortura hedionda sofrida por um rapaz morador do Cambuci, cujo nome ou apelido era Antônio Comunista, mas que não tinha ligações com movimentos políticos).

... Não, para mim nada melhorou, aconteceu coisa pior.

... Sou um revolucionário nato mesmo, sou um revoltado, porque eu conheço a produção do Brasil, a grandeza territorial do Brasil e a miséria que existc no Brasil, num país farto. José Américo disse: 'a pior coisa é a gente morrer de fomc na fartura'. E assim ć o Brasil, um país farto de tudo, e hoje no café estava falando para minha mulher, como é essa terra, farta de tudo, não temos um homem no Brasil, só tem ladrão. De 64 para cá não se vê um político no Brasil, esses desonestos, isso é o que tem, quanto mais você roubar, mais eu vou passear lá não sei aonde.

... O brasileiro sente as coisas e não sabe explicar. Sente fome, sentc a paciência e a tolerância. Về esse Estado de Emergência, esse Presidente nosso dá conselho para 400 ou 600,400 e tantos são deputados e 200 e tantos são senadores. Um homem só dá conselho para 700 homens. Será que naqueles 700 não tem um que tenha juízo, ou são todos malucos, ou então o maluco é elc por consentir malucos na companhia dele. Sobre o que esses malucos podem legislar? Nada. Eu acho que o Figueiredo é vítima de algum safado lá dentro, 
eu me esqueci, eu sou simpático ao Figueiredo, mas eu acho que ele é enganado por alguém, como Getúlio foi por Samuel Weiner.

... Não se progride pelo direito nem pelo cumprimento do dever, e sim pelo apadrinhamento. É lamentável o que acontece no Brasil hoje." (Gráfico, 73 anos. Entrevista concedida a Jorge Galdino Ferreira. São Paulo, 12/11/1983)

O testemunho dado por um militar enfatiza a divulgação de valores cívicos e atividades coletivistas como um ponto positivo do Estado Novo. Justifica os golpes de 37 e 64 pela necessidade da implantação da ordem, sendo que o Congresso representava a desordem:

"Eu não posso dar uma opinião muito abalizada sobre esse assunto porque eu era militar e o Estado Novo foi em 37. Naquela oportunidade, a situação quase era a mesma de hoje, não havia uma coordenação, não havia uma coisa mais coordenada. Então o Estado Novo foi implantado tendo em vista mais ou menos o que aconteceu agora em 64, na Revolução de 64, e inclusive porque as coisas nāo estavam correndo bem. O Congresso, principalmente o Congresso, a Câmara c o Senado, eram virtualmente contra Getúlio, porque Getúlio já tinha uma série de pontos contra, inclusive a revolução constitucionalista de 32. A única saída que o Getúlio e os (atuais) governantes podiam fazer era decretar um Estado de Emergência, de quase ditadura, então foi feito o Estado Novo.

... O executivo teria que ter mais poderes para implantar determinado, por exemplo, para implantar indústria nacional, a Petrobrás, a fábrica de motores e lcis trabalhistas. Tudo isso teve oposição, então era preciso que ele tivesse força suficiente para decretar aquilo e pronto. Não tinha mais assunto para que as oposições não atrapalhassem, aliás o seu papel é de protetor.

... No período do Estado Novo houve modificações até no Exército que era mal preparado, mal pago, mal armado, mas era uma instituição que não reclamava, pois isso é uma virtude militar. Aceitavam-se as ordens superiores e não se discutia. Em 35 começaram a melhorar os vencimentos. Em 37, quando foi constituído o Estado Novo, o exército começou a vibrar, a viver. Por exemplo, muitos soldados e até graduados não sabiam cantar o Hino Nacional. Cada corporação, cada regimento, cada unidade tem sua canção preferida, mas a grande maioria não sabia sua canção, nem o Hino à Bandeira, à Pátria, aquelas coisas e tudo o mais. Em 37 foi implantado esse regime: todos os dias de manhã, às 7,45 hs., o regimento formado com a banda de música, cantava-se o Hino Nacional, todos, o comandante na frente. Cantava-se a Canção às Armas, o Hino à Bandeira. Então aquelas bandas marciais, aquilo começou a dar um elã, um certo crescimento nas Forças Armadas. Era universal isso, todo o país fazia isso. Foi instituída, por exemplo, a Semana da Pátria e o Dia da Juventude, quando desfilavam estudantes juntamente com o regi- 
mento. Era uma semana inteira de festejos. O Exército começou a receber coisas novas: $o$ antigo uniforme caqui, as perneiras. Então houve aquela mudança toda para melhor.

... Isso foi uma das coisas boas que aconteceu para o Exército, porque aí vieram aquelas normas. As normas traçadas pelo Estado Maior, instituídas pelo governo. Aquilo era rigorosamente cumprido. Entre clas o ensino de Educação Moral e Cívica. Todas as semanas cra escalado um oficial para fazer uma palestra para a tropa onde eram recordados feitos do Exército, como da Guerra do Paraguai e outros de exaltação à Pátria. Então isso foi o que aconteceu de bem, de bom para o Exército. Eu acho que inclusive a própria juventude gostava, sabe? Todos os colégios, nas praças, nas ruas desfilando, praticando esportes..." (Militar, 74 anos, preferiu permanecer anônimo. Entrevista concedida a Luciana Moniz Freire, sem data)

O depoimento a seguir, de um anticomunista, responsabiliza o ensino pela revolta da juventude. De certa forma, complementa o pensamento do depoente anterior porque, ao constatar mudanças substanciais nas atitudes dos jovens, tenta apontar os culpados pela perda dos antigos valores.

"(Getúlio Vargas) era uma pessoa humana. Ele foi muito mal assessorado. Não é mal assessorado... ele foi excessivamente violento por intermédio de um chefe de polícia, coronel Müller, Filinto Müllcr, de Mato Grosso, que era o Chefe de Polícia. E era um trabalho anticomunista. Então havia o sistema da delação. Havia a dclação dentro das fábricas, dentro das escolas, dentro das repartições... e o sujeito abria a boca e já cra taxado de comunista. E, em São Paulo, ia para o Presídio de Maria Zćlia, célebre presídio em frente à Rua Belém. A indústria do Matarazzo foi transformada $\mathrm{cm}$ presídio. $\mathrm{E}$ as atrocidades... o sistema era uma barbaridadc... cra totalmente ignorado, como eu acredito que muito do povo da época o ignorava como ignoram hoje.

... Agora o que existe é o seguinte: esta é a subversão comunista pura e clara.

... a maior propaganda comunista é a corrupção dos hábitos, dos costumes e da família. Primeiro ato é corromper os costumes para fazer a lavagem cerebral, a primeira coisa. Tem estudante aí, você na hipótese está com 20 anos, ou 21 anos ou 19. Muito bem, a Revolução foi em 64, você pode contestar o quê? Se você não conheceu, não vivcu. Mas então você não pode contestar. A vida antes era melhor, não tem dúvida nenhuma, era melhor. $\mathrm{O}$ que houvc era o seguinte: houve uma lavagem cerebral nas escolas, maus professores, uma imensidades de faculdades. Há faculdades do interior que não cxigem nem a freqüência, nem conhecem o aluno. Gentc mal formada. Acabou.

... E o resultado é isso que você vê. A mocidade toda aí, inutilizada. Pobre do país que tiver os jovens que nós temos aqui." (Funcionário público esta- 
dual, 69 anos, preferiu permanecer anônimo. Entrevista concedida a Regina Burkhardt. São Paulo, 26/11/1983)

Por seu aspecto mais teórico, destaca-se no conjunto documental o depoimento do jornalista trotskista Fulvio Abramo:

"O Estado Novo foi a tentativa de organização do Estado Totalitário no Brasil. Totalitário e reacionário para defender-se contra os movimentos operários ascendentes e para dar força política ao grupo que estava ainda contestando o poder, aos grupos tradicionais da burguesia brasileira, ou seja, a burguesia cafeeira de São Paulo e a burguesia baseada na pecuária de Minas Gerais.

... O Estado Novo no Brasil, realmente, organizou o Estado Nacional em bases firmes e contra a dispersão da federação. A federação perdera a sua característica principal de distribuição de democracia do poder, tornou-se um Estado praticamente de tendências unitárias e estas tendências foram desde cntão sc accntuando até chegar ao ponto atual que culminou com essa Revolução de 64 que fez, realmente, do país um Estado centralizado c não uma federação.

... Bom, em relação à organização das massas, muito embora feita através do sindicato oficial, dialeticamente teve o seu aspecto favorável porque, pelo menos, centralizou os operários em torno de suas organizações. É verdade que limitadas as suas capacidades de expressão e profundamente corrompidos pclo poder, mas de qualquer maneira foi a coisa mais característica do Estado Novo. Além disso, foi a eliminação da influĉncia do remanescente sistema feudal na agricultura e do poderio dos senhores de terra, favorecendo a ascensão ao poder político das classes empresariais e industriais; portanto, a transformação do Brasil num país moderno e isso foi sem dúvida o trabalho que o Estado Novo realizou. Primeiro permitiu, num dos seus pólos, a rcorganização, a organização dos opcrários e grandes massas pelo menos arregimentadas e, por outro lado, realizou a revolução do poder, tirando o poder das classes agrárias e transferindo para as classes cmpresariais.

... Getúlio Vargas nesse período, eu me lembro, como durante toda a sua vida mostrou uma coisa que, evidentemente, ninguém pode negar; ele foi provavclmente um dos únicos, senão o único grande estadista brasileiro. Estadista no scntido de que ele sabia trabalhar com os elementos da política nacional, tendo uma visão muito concreta sobre cada um deles e sabendo tratá-los com grande habilidade política - empregando o uso da brutalidade quando fosse necessária para atingir os scus objetivos - e dar-lhes uma solução. Haja vista os dois grandes problemas que ele resolveu ao mesmo tempo: o abandono da política favorável ao Eixo e a criação das bases para o desenvolvimento industrial com a criação de Volta Redonda." Jornalista, 74 anos. Entrevista conccdida a Selma C. Nunes. Osasco, 5/11/1983) 
Em extensa entrevista, na qual proliferam narrativas sobre o cotidiano do trabalho jornalístico e seu contato com políticos da época, Nelson Cunha Azevedo testemunha o fascínio que Vargas exerceu sobre ele, relativizando, como os demais, o desrespeito aos direitos humanos cometidos pelo Estado Novo em relação à violência da revolução de 64 .

"As lembranças que eu guardo são estas: um grande cerceamento da liberdade, mas não tão exagerado quanto diziam; hoje, por exemplo, esses últimos vinte anos da Revolução de 1964 eu acho que deixam aquele período de cerceamento de liberdade do tempo de Getúlio, deixariam reduzido a uma pequena coisa. Havia censura nos jornais, havia prisões, admito até que houvesse alguma tortura nessa época, mas muito longe do que ocorreu recentemente no Brasil, não é?

... de certa maneira nós não tínhamos os grandes problemas de hoje, não tínhamos a grande dívida que temos hoje, não é? e o país, me parece que dentro da relatividade, caminhava normalmente apesar do rótulo de ditadura que se imprimiu a esse período.

... Olha, geralmente neste período, Getúlio é apresentado por alguns dos seus mais ferrenhos adversários como um ditador, a excmplo de Hitler ou a exemplo de Mussolini. Todas as pechas e todos os adjetivos foram lançados sobre Getúlio neste período, anteriormente a csse período c posteriormente a esse período. Não entendo quc essa posição tremendamente, violentamente, contrária ao período do Estado Novo, e portanto à gestão de Getúlio, tenha justificativa. É verdade que ocorreram muitas irregularidades, é verdade que ocorrcram muitas prisões, ... mas também ć preciso lembrar que nós estávamos numa época muito difícil, às vésperas da Segunda Guerra Mundial. ... Meu ponto de vista pessoal é que, com todas as suas falhas, o Getúlio foi um homem extraordinário. Talvez muita gente tenha vergonha de dizer isso. Eu me sinto perfeitamente à vontade para dizer, porque nunca dependi dele em coisa alguma, nunca, eu, soldado de 1932.

O único contato que eu tive com Getúlio foi quando ele já era presidente, e se encontrava no Palácio Rio Negro, em Petrópolis. Eu trabalhava num jornal aqui de São Paulo, A Gazeta, e o país cstava muito exaltado e movimentado por problemas relacionados com o Estatuto da Terra, que estava para ser baixado, e também com a Reforma Agrária. Então, cu fui entrevistar Getúlio, mandado pelo diretor de $A$ Gazeta.

$A$ Gazeta tinha sido um jornal tremendamente adverso ao Getúlio, tanto assim que o seu diretor Casper Libero chegou a ser exilado. Fui entrevistá-lo em Petrópolis e, para minha grande surpresa, para mim que tinha sido soldado em 1932 e lutado contra ele, a personalidade dele me cativou tremendamente. Um homem extraordinário, objetivo, quase carinhoso por assim dizer, 
sem ser paternalista. Não foi fácil, evidentemente, eu me aproximar dele, porque logo à entrada do Palácio Rio Negro estavam os seus chamados capangas, chefiados pelo negro Gregório. Foi o próprio Gregório que efetivou a minha aproximação com Getúlio. O Gregório com aquela simplicidade e mordacidade dele disse: 'É... agora a canalhada de São Paulo toda está atrás do Presidente!'. O Presidente estava no auge nesta altura e eu, naturalmente, estava incluído entre a canalhada, não é? (risos). Mas a minha função era uma função profissional e logo depois o Gregório disse: 'Eu vou arrumar para você conversar com o Presidente, ele vai sair logo após o almoço, e você vai falar com ele na calçada, ele faz uma caminhada de quatro quilômetros por Petrópolis, e você vai conversar com ele'.

Daí a pouco o Presidente saía de branco, usava-se muito terno de linho branco nesta época, a gente chamava linho 120, com o seu chapéu Panamá, era tempo de calor e, aliás, era sempre uma característica dele o chapéu Panamá c o charuto, inseparável, charuto recentemente aceso, atravessou aqueles portôes de ferro do Palácio do Rio Negro, que era a residência de veräo do Presidente, e começou a caminhar. Eu fui acompanhando a uma certa distância, até que o Gregório, o crioulo, fez sinal de que eu poderia me aproximar do Presidente. Eu me aproximei e ele me recebeu com a maior naturalidade do mundo, pediu que eu o acompanhasse, fui conversando com cle e no fim eu já estava com a língua de fora, porque ele andou quatro quilômetros em Petrópolis, parando nas esquinas para dar níqueis para os garotos comprarcm sorvetes. Parando no mirante, finalmente, lá no alto, ele deu-me a entrevista que cu precisava sobre a tal história do Estatuto da Terra e da Reforma Agrária, tranqüilizando, de certa maneira, os fazendeiros e lavradores de São Paulo, especialmente os da Sociedade Rural Brasileira, que estavam muito exaltados com as providências a serem baixadas pelo Governo Federal. Achei-o uma figura, falando sob um ponto de vista assim de personalidade, de pessoa, uma figura extraordinária. E também devo dizer que reconheço que ele foi um grande estadista. É bobagem querer esconder isto, porque no Brasil ninguém esconde, não é?, foi um grande estadista, um grande presidente, um grande ditador, sc quiserem assim, mas a verdade é que ele marcou o país com iniciativas que, a medida que o tempo vai passando, nós vamos valorizando cada vez mais." (Funcionário público, professor c jornalista [diretor de $A$ Gazeta], 71 anos. Entrevista concedida a Maria do Carmo A. Mattos. São Paulo, 31/10/1983) 


\section{FIM DO ESTADO Novo}

A entrada do Brasil na Guerra, em 1942, ao lado dos Aliados contra as potencias do Eixo, surpreendeu a muitos que esperavam poder o Brasil manter-se neutro no conflito ou, em extremo, entrar na guerra ao lado de Berlim, Roma e Tóquio. Impressões falsas. A dependência econômica do país em relação aos Estados Unidos não permitia tais atitudes.

A política econômica intervencionista de Vargas, favorecida pela desorganização dos mercados internacionais, devido ao início da Segunda Guerra Mundial em 1939, acabou por favorecer a canalização de capitais para a indústria de bens de consumo. Com as dificuldades advindas da guerra, as importações tornaramse dificeis e as exportações foram favorecidas, principalmente os de café, borracha, quartzo e fios de seda. A indústria nacional, ainda muito centrada na produção têxtil, começou a diversificar sua produção, recebendo incentivos públicos através de medidas cambiais, fiscais e créditos especiais. Intencionalmente o governo favoreceu esse processo, investindo em indústrias de base e nas áreas de transportes e serviços públicos.

A caminhada para a redemocratização iniciou-se logo a seguir. Relaxada a censura do DIP, as contestações ao regime multiplicaram-se. A oposição ao Estado Novo começou a se manifestar em vários Estados, envolvendo diferentes setores da sociedade. Comunistas, socialistas, liberais, intelectuais e estudantes aglutinaram-se em frente-única contra a ditadura. Campanhas pela anistia aos presos políticos surgiram em todo o território nacional, em grande parte encabeçadas pela União Nacional dos Estudantes, UNE, órgão do movimento estudantil recém-fundado no Rio de Janeiro. Greves e movimentos de rua acabaram, na prática, com a censura do Estado Novo. A população acolheu com euforia o decreto de anistia aos crimes políticos, assinado em 18 de abril de 1945. Exilados retornaram ao país e presos políticos foram libertados do cárcere.

O relato do Prof. Ruy Coelho oferece perspectivas do movimento estudantil e intelectual às vésperas do fim do Estado Novo.

"Como estudante (do ensino superior) nós estávamos totalmente na oposição. Isto é, Getúlio representa uma etapa que estava findando no Brasil. ... (Começava) a democratização, isto é, num certo momento Getúlio passou a ser alguma coisa de muito perigosa, porque era um homem apegado a uma estrutura de massacres, mas tinha um poder imenso de mobilizar as massas. De modo que o obstáculo que nós víamos era o Getúlio. E isto criou uma certa ilusão - à distância eu vejo -, a idéia de que acabando com o Getúlio e com o getulismo estava tudo resolvido, compreendem? Então, a democracia no Brasil era isso: como primeira coisa o combate ao Getúlio. 
... Do ponto de vista político ia-se formando uma organização clandestina para dar combate ao Getúlio. Existia um grupo que se chamava Comitê de Ação, e por causa disso eu fui fichado como comunista. Nós nos aconselhávamos muito com a geração anterior. Acho que nisso somos um pouco diferente de vocês. (risos) O slogan 'desconfie de toda pessoa que tenha mais de 30 anos' não existia. Nós confiávamos muito em pessoas como Mário Schemberg, que era do PC e Caio Prado Jr. Quando começou a conspiração, nós nos reuníamos nos fundos da Livraria Brasiliense, no Atelier do Bruno Giorgi, um grande escultor, em várias casas. O Comitê de Ação reunia uma série de gente à esquerda.

Os estudantes estavam na oposição em torno do Centro Acadêmico XI de Agosto, que era liberal, comportando várias tendências. A grande maioria estudantil mais tarde iria formar os grupos que entraram para a UDN - caso do Abreu Sodré. Não havia uma posição de direita, havia uma posição de centro mais liberal e esquerda. Não havia propriamente uma direita. A grande maioria e a esquerda estavam com a idéia de fazer alguma coisa em comum, e sobretudo fazíamos o que nos aconselhavam as pessoas experientes do 'partidão': 'não accitem provocações, nada de revolta gratuita'. O grupo comunista tinha a idéia de colaboração franca com todas as forças liberais.

Foi então que circularam boatos de que Luís Carlos Prestes, da prisão, tinha enviado a palavra de ordem para que se desse apoio ao Getúlio. Mas ninguém acreditou nisso, até a saída do Prestes da prisão. Aí é que houve a cisão, porque havia um grupo do PC, chamava-se Comitê Nacional de Organização, que estava organizando o partido para dar apoio ao Getúlio. Isto nos pareceu monstruoso da parte de um homem que tinha sido torturado, preso e sofrido tanto. Pessoas de São Paulo e do Rio, que tinham se aliado aos liberais tiveram que se retratar. Lembro de Astrogildo Pereira, um dos grandes cérebros do PC, um homem calmo, de cultura literária - fez trabalhos sobre Machado de Assis e tudo o mais -, e que fora ccgado pela polícia, foi obrigado a escrever alguns artigos dizendo que tinha errado até aquele momento.

Então o nosso grupo se formou - antes mesmo da saída do Prestes, quando o PC se organizou para dar apoio ao Getúlio e aí tentar talvez um golpe -, chamou-se Esquerda Democrática, integrada por Rogê Ferreira, Sérgio Milliet, Luiz Martins, eu e outros. A Esquerda Democrática teve um momento de clandestinidade, depois apareceu às claras. Transformou-se no PS.

... Durante uma das manifestações de rua estudantis, em 1944, fui preso. Ah! Naquele tempo não se prendia gente de uma certa classe social por muito tempo. Eu fiquei preso dois dias. Era outra coisa, como diz o Paulo Emílio Sales Gomes. Naquela época a tortura era artesanal. Não existiam esses apareIhamentos todos. Eu vivi duas repressões: a do Estado Novo era idílica, uma escola risonha e franca perto da que veio depois - o regime que nós vivemos. 
Tentamos fazer várias coisas. Por exemplo, Mário Neme organizou o livro Plataforma de uma geração em 44. Aí escrevemos todos: Antonio Candido, eu. Foi uma tentativa, de maneira muito disfarçada para não atrair a censura, de precisar certos rumos que a mocidade trillhava. Essa série de depoimentos é interessante. Lendo hoje, vocês achariam que, perto da censura no regime ditatorial atual, os disfarces das opiniōes não eram tão necessários. Lia-se nas entrelinhas, mas era muito mais declarado do que qualquer outra coisa que tenha aparecido nos jornais e revistas do regime atual. Por exemplo, o livro Fazenda Modelo, de Chico Buarque, é tão cheio de alusões que quando saiu pareccu-me ter compreendido tudo e, outro dia, fui relê-lo e não comprcendi mais. É tão cheio de alusões que a gente não sabe mais a que se referia.

... Num determinado momento o Getúlio foi obrigado a declarar guerra contra o Eixo, num movimento extremamente forte. $\mathrm{E}$ ainda me lembro, estou neste momento vendo fotografias, nas primeiras páginas dos jornais, dos cadávcres dos marinheiros e toda gente que fazia cabotagem. O navio da Marinha fora afundado por submarinos alemães. Vocês podem imaginar o impacto que tinha isso na opinião pública. Com isto ocorre um movimento cnorme. Getúlio não era mais útil às classes dirigentes, porque nós tínhamos jogado a cartada dos Aliados. As potências do Eixo começaram a sofrer reveses muito grandes depois da retirada da Rússia. O espectro do nazismo e do fascismo não amedrontava mais. Mas eu não sou daqucles que acreditam unicamente numa política assim, somente por interesses políticos. Havia também uma certa simpatia pelos liberais brasileiros, um acordo, uma causa comum: a idéia era de um Brasil democrático que não contrariava os interesses de ninguém, nem das classes dirigentes, nem dos intelectuais. O povo estava ao lado do Getúlio, que era populista.

A queda da censura do Estado Novo sabem como se fez? Com a publicação da entrevista de Carlos Lacerda com José Américo de Almeida e, de repentc, uma palavra de ordem: não há mais censura. Simplesmente se desobedeceu à censura, maciçamente. Foi uma coisa que entusiasmou. Foi uma palavra de ordem do Brasil, de Norte a Sul.” (Depoimento já mencionado)

Como já anuncia o relato acima, a questão eleitoral tornou-se o centro das reivindicações das oposições, anteriormente emudecidas, enquanto no governo e no exército deram-se significativas cisões. Getúlio tentou, mas não conseguiu conter a onda eleitoral.

Várias entrevistas referem-se à Força Expedicionária Brasileira. A FEB, atuando na Itália contra os alemães e saindo-se vitoriosa da guerra mundial, evidenciou o paradoxo de brasileiros lutarem pela democracia no exterior estando seu país sob uma ditadura. Ambições políticas do alto comando militar também pesaram no novo contexto eleitoral. 
A campanha eleitoral deslanchou com o aparecimento de novos partidos políticos. A União Democrática Nacional, UDN, lançou a candidatura de Eduardo Gomes, tradicional inimigo de Vargas. O Partido Social Democrático, PSD, formado sob a égide governamental, propugnava pela candidatura do general Eurico Gaspar Dutra, ministro da Guerra, que não possuía ainda o apoio definitivo de setores do governo e do próprio exército. A data das eleições foi fixada para 2 de dezembro de 1945 e a liberdade partidária foi restabelecida.

Manobrando de todos os lados e contando com sua popularidade entre os trabalhadores, Vargas criou um fato político novo. Tratava-se do lançamento do movimento intitulado Queremismo (corruptela de "Queremos Getúlio") e cujo lema era Constituinte com Getúlio. Diversas organizações sindicais e associações identificadas com o governo promoveram comícios queremistas que mobilizaram massas populares.

De forte impacto nos narradores foi o engajamento de Prestes na campanha, após nove anos de isolamento numa prisão durante os quais sua mulher, Olga Benário, havia sido entregue à sanha nazista e sua filha nascido em um campo de concentração. Mas diversas circunstầncias implicaram nesta decisão política de Prestes. Por um lado, pronunciamentos do embaixador norte-americano que "pedia", isto é, exigia do governo garantias para as eleições, em aberta intromissão nos negócios internos do país. Por outro lado, Vargas aproximava-se cada vez mais das posições da esquerda nacional ao decretar a lei antitrustes e antimonopólios, criando uma comissão autorizada a desapropriar qualquer organização lesiva aos interesses nacionais no intuito de conter o aumento do custo de vida. Os comunistas apoiaram entusiasticamente todas essas iniciativas.

Uma questão que se coloca para a compreensão desse momento é que tendo Getúlio concretizado praticamente muitas das reivindicações populares, há anos encampadas pelos comunistas, o que lhes restaria fazer, além do que fizeram, para dar visibilidade ao partido recém-saído da clandestinidade? Na medida em que se organizavam as forças da burguesia o queremismo era a única possibilidade de participação política. Esta é ainda uma questão pendente entre intelectuais e militantes da esquerda brasileira.

As oposições desesperaram-se com as novas regras eleitorais estipuladas em 10 de outubro, que antecipavam as eleições estaduais, municipais e nacionais para o mesmo dia 2 de dezembro. Anteviam grave perigo na hipótese dos getulistas conseguirem os cargos municipais pois, assim, poderiam controlar os resultados das eleições nacionais a seu favor. Temia-se também que Getúlio, inspirado na volta ao poder de Perón na Argentina, instituísse uma República sindicalista no Brasil e revertesse o processo de redemocratização (Carone, E. O Estado Novo (1937-1945), p. 347). 
Forte nas rememorações foi a atitude "fatal" de Vargas em comunicar a João Alberto, chefe de polícia do Distrito Federal, que este cargo seria ocupado por Benjamim Vargas, seu irmão, pessoa considerada suspeita pelos militares. Isso foi um pretexto para que Góes Monteiro e João Alberto arregimentassem os militares contra o presidente e o general Eurico Gaspar Dutra, embora, às vésperas das eleições, apresentasse a Vargas um ultimato: ou desconsiderava as ordens que dera ou seria deposto. Este negou-se a voltar atrás e em 29 de outubro renunciou ao cargo. A iniciativa de sua deposição foi assumida publicamente por Góes Monteiro, em nome do Alto Comando do exército patenteando, assim, a não participação dos políticos liberais constitucionalistas no evento.

\section{UMA HISTÓRIA SEM EPÍLOGO}

Mas nem a história nem a memória terminam aqui. Nosso texto omitiria aspectos significativos da pesquisa realizada, entre eles as inúmeras menções à morte de Vargas e a seu último governo. Voltando à arena política Vargas foi eleito senador por dois estados - São Paulo e Rio Grande do Sul -, tendo assumido a legenda do PSD do RS. Pouco presente no Senado, continuou a articular a política nacional de sua propriedade rural, em São Borja, e a fortalecer a organização do Partido Trabalhista Brasileiro. Voltaria ao poder para o mandato presidencial de 1951 a 1955, democraticamente eleito pela coligação PTB e PSP (partido organizado pelo político paulista Ademar de Barros), sufragado por mais de 48,7\% do eleitorado.

Seu último governo desenrolou-se sob o clima de intensas paixões. Dizem os depoentes que o passado jamais foi enterrado por seus inimigos. A União Democrática Nacional, UDN, concentrou em suas fileiras todos os ressentidos. Estes passaram a mover ferrenha e constante oposição a Vargas no Congresso Nacional e na mídia. Escândalos sucessivos eram veiculados diariamente. Em geral, as denúncias recaíam sobre a ação dos assessores do presidente e membros de sua família. Vargas era acusado de permitir abusos de poder e cooptar seus inimigos, concedendo-lhes maior influência. Dizia-se que Getúlio aparentemente não era uma pessoa corrupta, mas sim, um grande corruptor.

Seus mais próximos assessores não conseguiam administrar o país e muito menos enfrentar com habilidade tantos confrontos políticos. A reação do círculo próximo ao presidente foi desastrosa. Em agosto de 1954, por sugestão de influentes getulistas, Gregório Fortunato, elemento da guarda pessoal de Vargas, encomendou a pistoleiros o assassinato de Carlos Lacerda - deputado udenista e jornalista carioca do Tribuna da Imprensa - que, pela rádio Globo e pela TV Tupi, 
pronunciava inflamados discursos, procurando desmoralizar o governo. $\mathrm{O}$ atentado deu-se na madrugada de 5 de agosto, segunda as narrativas sem o conhecimento de Getúlio. Durante o tiroteio Lacerda foi ferido e seu acompanhante, o major da aeronáutica Rubens Florentino Vaz de Mesquita, foi morto.

A oposição reagiu imediatamente. Articulou-se uma grande campanha nacional exigindo a renúncia do presidente. Nesse sentido, em São Paulo, promoveuse um grande comício no Largo de São Francisco, liderado pelo Centro Acadêmico XI de Agosto da Faculdade de Direito da Universidade de São Paulo, tendo sido distribuídos crachás com a letra $R$ de renúncia. Publicamente pessoas ostentavam em suas vestes sua posição política, mas a maioria silenciosamente aguardava os acontecimentos.

Nesse meio tempo, as Forças Armadas exigiram o afastamento de Vargas, enquanto se formava o inquérito sobre o atentado. Getúlio Vargas, sem alternativas, assentiu; antes porém de transmitir o cargo suicidou-se em 24 de agosto de 1954, provocando uma comoção popular jamais presenciada no Brasil. No lugar do alarido de jovens estudantes renuncistas, as ruas foram ocupadas por multidões de operários que de braços dados pranteavam a perda de seu protetor. Estes acontecimentos são ainda relatados com visível emoção por muitos entrevistados.

Em algumas lembranças, cuja ordem cronológica dos fatos obedece a critérios psicológicos, encontrou-se a afirmação de que Vargas assumiu o poder em 30 e dele saiu, assassinado por seus inimigos, em 1954. Enquanto a confusão cronológica foi expressa por depoentes que não tiveram acesso à educação formal, a inaceitação do suicídio não pode ser explicada por esse critério.

Sob o ponto de vista afetivo, a versão de que Vargas foi assassinado e não cometeu suicídio talvez expresse o sentimento popular de perda da segurança representado por sua presença constante e a recusa filial em aceitar o voluntário abandono paterno.

Procurando racionalizar esta inaceitação um entrevistado emitiu a seguinte opinião:

"Não acredito que elc tenha se suicidado, é uma coisa interessante, não acredito. Não acredito, não tinha nenhum indício de que ele seria um homem capaz do suicídio. Não acreditei quando recebi a notícia de que cle havia se suicidado, como também não acreditei na Carta Testamento que se diz deixada por ele. Não acredito que aquele homem tivesse condições, e nem dessa coisa meliflua e um pouco choramingas que é a Carta, embora muitos exaltem o seu estilo político e literário. Não acredito qụe ele tenha se suicidado, não era homem para se suicidar. Era um homem, como eu disse a você, temos que reconhecer, fora de série, que cometeu erros tremendos, talvez contra si e 
sua família maiores do que os cometidos por ele contra o Brasil. Tanto que você vê uma coisa, são passados vários anos e o que se diz da sua vida durante presidente, ditador, dispondo de tudo no país. Naturalmente que seus arquivos foram vasculhados, naturalmente que houve mais do que tempo para que os pesquisadores $\mathrm{c}$ a história mostrassem o que este homem fez, e não se levantou, não conheço até hoje, uma coisa de corrupção da parte dele, embora - Carlos Lacerda, que neste ponto o tremendo político que era, e tribuno, ter definido o scu governo, certo período seu, como um mar de lama no Palácio do Catete. Se este mar de la ma existir, você pode ficar certa que não era com a conivência, com o conhecimento delc. Acredito que talvez alguma omissão dele, mas ele pessoalmente era uma figura que você sabc, agredida por todos os lados, mas nunca ninguém apontou a metade da corrupção que hoje existe no Brasil e que tenha sido praticada por clc." (Nelson Cunha Azevedo. Depoimento já mencionado.)

Reforçando a idéia da impossibilidade de Vargas encontrar outra saída a não ser a morte, o escriturário Vicente Salviatti depõe:

"Em 45 ele caiu. Aí ele voltou para a terra dele. Foi feita nova eleição e ele voltou como presidente da República, então continuou. Os descontentes continuaram minando o seu governo. Tanto é que depois cle acabou suicidandose. O povo o elegeu, para ele Vargas foi um verdadeiro rei ou coisa parecida. Mas ele não tinha sossego, não tinha colaboradores à altura. ... Tancredo Neves estava ao lado dele, mas os outros, os antigos perrepistas e udenistas andavam minando ainda, querendo comprar políticos que estavam do lado dele, aquele negócio todo. Quer dizer, o governo até 45, na queda dele, eu acredito que ele não se suicidou. Ele foi obrigado, não é?

... Embora tenha sido eleito pelo povo, não pôde governar como queria por causa da força de capitalistas americanos. Porquc o governo de Getúlio era um governo nacionalista. Por isso sofria a pressão dos capitalistas estrangeiros, que embargavam tudo. Vendo o que hoje nós temos aí, não resolve nada a nossa situação. Tudo o que se produz aqui pelas grandes indústrias, a Ford e a Chevrolet, volta para eles lá... Tudo que elcs instalam aqui reverte em lucros para eles. No governo do Getúlio ele queria fazer as coisas aqui mesmo. Para mim foram os estrangciros quc fizcram o Getúlio renunciar, ou o derrubaram, porque eles queriam impor um governo à moda deles." (Escriturário, 70 anos. Entrevista concedida a Marta Maria Revira. São Paulo, 11 de novembro de 1983.)

Também atribuindo responsabilidade à pressão estrangeira na queda e morte de Vargas, Alberto do Nascimento Henriques opina: 
"É, ele botou muita pressão em cima do povo, até que o povo desgostou c começou a, a desguiar, não é? Deram o alarme para a deposição e ele não quis se depor então falaram, 'vai lá no quarto dar um tiro na cara dele lá'... e o cara foi lá c tam... olha, suicidou-se; ninguém sc pode suicidar assim não, desse jeito, ninguém se pode suicidar, está na cara. A filha dele sabe como foi, sabe qucm foi, ela viu matar o pai dela, mas ela não pode falar, se falar hoje amanhã cla é morta... Quem matou foram os amigos dele lá do palácio. O amcricano falou: 'olha, vai lá c mata ele, não quer sair por bem vai por mal.' Mataram elc e pronto, chegaram lá e deram um tiro no peito dele.

( $\mathrm{Da}$ forma) como ele suicidou, ninguém se suicida, todo mundo sabe disso. Ninguém vira o revolver assim... pode dar o tiro na cabeça, mas ninguém vira o revolver para o coração, não dá para virar." (Carpintciro, português, 77 anos. Entrevista concedida a Eduardo J. Afonso. São Paulo, 23 de outubro de 1983.)

\section{$* x *$}

Poder-se-ia multiplicar as opiniões à exaustão sem chegar a nenhuma interpretação muito mais abrangente, mesmo porque a memória constituída sobre Getúlio, define-se segundo a ótica multifacetada das relações pessoais do depoente, de sua inserção no mercado de trabalho, dos credos políticos assumidos e tantas outras condições particulares. Evidentemente, depoimentos de pessoas selecionadas sob outros critérios, com um único recorte profissional, como por exemplo exclusivamente políticos ou intelectuais, apresentam uma construção memorialística diferente da aqui exposta, tanto na forma quanto no conteúdo, mas a opinião desses grupos tem sido bastante divulgada. Aquilo que poderia ter sido desfavorável à pesquisa, isto é, uma certa escolha aleatória dos entrevistados - no sentido de que cada pesquisador teria recorrido àquele que lhe estivesse mais próximo - acabou por ser bastante proveitoso, permitindo constatar algumas constâncias relevantes em depoimentos de pessoas de diferentes estratos profissionais com variado grau de instrução. Vejamos algumas delas.

Causa admiração a familiaridade da maioria dos entrevistados com o passado público, sendo que alguns fazem mesmo menção ao fato de possuírem um conhecimento sobre o tema superior ao do entrevistador, usando expressões como estas : "A geração de hoje não sabe mais destas coisas..."; "Os jovens de hoje não se aconselham com a geração mais velha e ficam sem saber das coisas, achando que descobriram o mundo..."; “O que eu vou contar vocês não encontram nos livros..." Assumiram desta forma um tom professoral, favorecido pela pouca idade dos entrevistadores, mas isso também se repetiu com pesquisadores mais expe- 
rientes ao lhes perguntarem em que ano haviam nascido, para concluir que uma pessoa de quarenta e poucos anos não poderia saber muito sobre a época rememorada. Ao contrário das gerações posteriores que perderam contato com a história política, fenômeno acentuado pela ditadura militar e pela crise da educação nacional, os entrevistados - todos com mais de sessenta anos - consideram-se donos de um saber precioso e por isso conduziram sua narrativa com autoridade, muitas vezes interrogando os pesquisadores sobre nomes ou acontecimentos que se lhes escapavam, acrescentando "logo me lembrarei..., vocês não conheceram ele mesmo...".

Não foram raros os que encerraram suas entrevistas deixando-as em aberto: "Muito, muito mais teria a falar, mas..."; "Esta história não acaba aqui..."; "Eu vou parar aqui, mas se quisesse não acabaria mais de tanta coisa que tenho para contar..."; "É uma pena estar terminando, porque nesta época aconteceu tanta coisa e hoje nem se fala nisso..."; "O que existe hoje é resultado de tudo isso..."; "Esses homens que aí estão mandando se fizeram naquela época...". Para esses depoentes a história política é um processo contínuo e se explica pelo encadeamento dos acontecimentos, comportando, entretanto, desvios e rupturas que the tiram o caráter determinista como explicitam: "O imperialismo americano impediu o Getúlio de fazer o que queria..." ou "Os inimigos de Getúlio o mataram para que ele não realizasse mais coisas para o povo..." e ainda "A vida é isso aí, parece que tudo vai para um lado, de repente vêm uns generais e vai para outro...".

A experiência da participação política realiza-se de várias formas na sociedade, inclusive no desejo de compartilhar com a nova geração um conjunto rememorativo sobre o passado da esfera pública. Isso aproxima as gerações em convivência, impedindo que os jovens vivam num presenteismo constante, fato que tem sido apontado por E. Hobsbawm. Mesmo que discordem das opiniões dos mais velhos - "...meus netos não pensam como eu, eles não gostam tanto de Vargas..." - acabam por se iniciar nas questões da cidadania a partir da unidade familiar, demonstrando a importância da transmissão da memória para a consolidação de uma identidade nacional.

Em várias sessões estiveram presentes filhos e netos dos entrevistados e suas interferências em surdina são sinais a serem observados: "Fale sobre aquele caso no Rio Grande do Sul, quando você conversou com o Getúlio..."; "Você sempre elogiou esse homem, agora está falando mal..."; "Ele não gosta do Lacerda..."; "Esse assunto é perigoso, é melhor parar... (sobre a ditadura militar)"; "Ela se emociona ao falar nisso..."; "Nunca se conformou com o suicídio..."; "Mostre aquele retrato assinado...”. Se por um lado esses comentários podem ser considerados impertinentes ou indesejáveis, por outro lado representam a eficácia da transmissão dessa memória a outros membros do grupo, entrevendo-se um novo depositário do conjunto rememorativo, futuro fiador de sua permanência. 
O imaginário sobre Getúlio Vargas é tão poderoso que oblitera a ação das demais figuras públicas contemporâneas e mesmo as que lhe são posteriores. Além disso, esse imaginário torna-o centro convergente das explicações construídas sobre o processo histórico, sobrepondo a personagem às diferentes conjunturas políticas e, ao fazê-lo, acaba por conceder-lhe um caráter atemporal. As menções às qualidades de Vargas - enigmático, esperto, calculista, manobrador, simpático, afável, carismático, inteligente, distante etc.- e as inúmeras anedotas contadas a seu respeito, nas quais se manifesta excepcional presença de espírito, tirocínio político e capacidade de sedução, são representações conotativas de atributos permanentes e inatos ao seu caráter.

Dessa forma, sua imagem se petrifica em um determinado momento, provavelmente durante o Estado Novo, não se atendo às contingências temporais que ocorreram durante o extenso período em que esteve no poder. Vargas é sempre o mesmo homem imperturbável e seguro, sem hesitações ou medos, sabendo como agir e premeditando com exatidão o próximo passo a ser dado. $\mathrm{O}$ imaginário obscurece todos os impasses próprios da condição política e as mudanças que ocorrem na personalidade durante uma trajetória de vida; Vargas permanece o mesmo, o homem de 1930 pré-figurava o de 1954.

Não houve da parte de nossos narradores nenhuma menção significativa aos militares que sempre dividiram o poder com Vargas. Prefiriram concentrar no golpe de 1964, sua avaliação sobre a responsabilidade das Forças Armadas na implantação do estado autoritário. As representações comparativas entre o Estado Novo e a ditadura militar, desfavoráveis a esta última, empalideceram o "lado negro" do regime anterior, ao mesmo tempo em que afirmavam ser o presente uma experiência única e desalentadora, sem parâmetros no passado: "Hoje tudo é diferente, não há entusiasmo..."; "Vivemos um momento muito triste..."; "Vamos ver no que isso vai dar..."; "Antes havia esperança, alegria, agora..."; "A caserna, naquele tempo, era o lugar dos militares..."; “ Hoje ninguém pode falar nada..."; "A gente sai de casa não sabe se volta..."; “Os presidentes generais não dão satisfação a ninguém, Getúlio fazia sempre discursos explicando tudo..."; "Nunca se viu coisa igual, baixam a medida e pronto..."; "Até os patrôes têm medo..."; "Fazem o que querem... que milagre, que nada..."; "Não tinha essa divida de hoje, nem esses empréstimos...". Pode-se avaliar a violência das "medidas excepcionais" tomadas pelos governos militares pelo impacto que tiveram em uma sociedade acostumada a conviver sob o arbítrio dos detentores do poder político e econômico, para a qual a justiça variava segundo o estatuto social. O sentimento manifesto é que os governos após 1964 excederam-se em relação aos despotismos conhecidos e, por muitos, já interiorizados e aceitos. 
As representações sobre o suicídio de Vargas ressignificam, a seu favor, o papel que desempenhou na história do país ao acentuar seu isolamento em relação aos grupos e homens que o cercavam. Redimido das crueldades cometidas, sem o seu conhecimento, por Filinto Müller e pelos órgãos de segurança, injustiçado por Carlos Lacerda e os reacionários da UDN, pressionado pelo imperialismo americano, surpreendido e desolado pelos abusos cometidos pelo seu círculo de convivência, sua coragem pessoal reafirma traços de uma personalidade rara e excepcional. A convicção de que sua morte foi funesta para os destinos do Brasil gerou novas formas de reinterpretar o passado, projetando-se também no julgamento do futuro político do país. O mito se consolidou na memória, conservando sua potencialidade ameaçadora; não é ingenuamente que os neo-liberais no governo vêm repetindo: "É necessário por fim à era Vargas"...

São Paulo, 22 de abril de 1998.

ABSTRACr: The intention of this article is to analyze significant lines of the imaginary social presents in the depositions collected by the project "New State" in the Memory and in the Historiography. In the registered documental group, it is observed that the imaginary on Getúlio Vargas crystallizes during the "New State", isn't inscribing the temporary contingencies that happened during the extensive period while he was in the power. Vargas is represented as being always the same imperturbable and safe man, without hesitations or fears, knowing how to act and premeditating with accuracy the next given become. The narratives obscure all the own impasses of the political condition and the changes that happen in the personality during a life trajectory; the man of 1930 prefigured the one of 1954. The comparative representations of the deponents on the "New State" and the unfavorable military dictatorship of 64 , to this last one, turned pale the "black side" of the previous regime, at the same time in that they affirmed to be the present an only different depressing situation, without parameters in the past.

PalaVRaS-ChaVE: social Imaginary - Getúlio Vargas - "New State" - military dictatorship of 64

\section{NOTA}

1. Projeto Estado Novo na Memória e na Historiografia, coordenação de Maria de Lourdes M. Janotti e descnvolvido por alunos da disciplina Brasil Independente II, períodos diurno e noturno do Departamento de História da FFLCH-USP em 1983. 